\title{
Research on the New Thinking Direction of Enterprise Marketing Strategy in the New Economic Era
}

\author{
Wei Han \\ Xi'an International University, Shaanxi, Xi'an, China, 710077
}

Keywords: New Economy; Enterprise; Marketing; Strategic New Thinking

\begin{abstract}
Enterprise development marketing has a very important role, it is related to whether the company has the correct market positioning, affecting the business is effective to achieve the purpose of business, and ultimately related to whether the enterprise can obtain the corresponding economic benefits to promote its steady development. In the context of today's new economic era, corporate marketing needs to constantly change the past strategic thinking to meet the requirements of the times. In view of the enterprise marketing under the new economic era, this paper mainly analyzes the background of the new economic era, analyzes the characteristics of the enterprise marketing under the background, and explores the strategic new thinking method of the enterprise marketing.
\end{abstract}

\section{Introduction}

Enterprise marketing is the key business behavior, how to achieve effective marketing and thus occupy a larger market is a major business goal. With the changes in the times and the market, Chinese overall economic development situation has shown great changes, and this time the enterprise marketing strategy also need to follow the change [1]. At present, Chinese economic development has entered the new economic period, on the enterprise marketing strategy related to the specific, as follows.

\section{The New Economic Era and Its Manifestations}

The New Economic Era. At present, Chinese society is in the new economic era, and the so-called new economy mainly refers to the more advanced economic development than in the past and the situation is through the full use of existing information technology to promote the rapid economic development of the economic model. Under the new economic era, the economic development environment is more open, the economic development situation is more optimized, and most of our enterprises are in the transformation and upgrading stage, the competition between enterprises is more intense [2]. In the present era, the technology is changing with each passing day, and the intensity and validity of policy support have been gradually strengthened. The new economic era has also come rapidly. The arrival of the new economic era has a very distinctive manifestation, namely, knowledge, network and low carbon green economy become more prominent.

The Manifestation of the New Economic Era. The main manifestations of Chinese new economic era are knowledge, network and low-carbon green form, which is the main form of the new economic era. First of all, the new economic era is the era of knowledge economy, so the current society attaches great importance to the cultivation of knowledge-based talent, attention to the development of knowledge technology, and thus the development of knowledge economy, the 
form of sustainable economic development is of great significance [3]. Especially in the case of the constant consumption of natural resources, the use of knowledge to implement economic development can greatly reduce the consumption of natural resources reduce the damage to the environment, but also to create greater economic benefits.

Second, the new economic era is also the era of network economy. Network and related technology is becoming more and more popular, the degree of information technology in various industries continue to improve, the enterprise's products, services, and so gradually to the way the network trading platform, more valuable industrial chain which also appears. For example, the era of network economy, pay more attention to and highlight the user or consumer experience and needs, on the basis of the business and business to create the economic benefits are gradually expanding.

Finally, the low carbon green economic model is also one of the manifestations of the new economic era. In the past, economic development was at the expense of the environment at which we lived, at the expense of the environment, and the current low-carbon green economic development under the new economic era was based on the past economic development model, , Low pollution, low emissions for the principle of economic development [4].

In the new economic era and its manifestation of the elaboration and analysis of the new economic era of knowledge, network requirements higher, at the same time also need to achieve low-carbon green economy development, the new economic era of the three main forms of reality But also complement each other, the production and service enterprises can first through knowledge, network technology to achieve low-carbon green economy development, and low-carbon green economy will continue to promote knowledge, network technology and other progress. In short, the new economic era to promote the development of the times, change the enterprise marketing model has a significant impact.

\section{The Impact Analysis of New Economic Times on Enterprise Marketing}

The arrival of the new economic era, the impact on the enterprise is very large, especially knowledge, technology to promote enterprise development has a significant impact. On the new economic era of the impact of corporate marketing, mainly reflected in two aspects:

The Products and Service Positioning of Marketing is More Diversified and Popular. The market is very important to the enterprise, so many enterprises in the process of marketing, based on the characteristics of the new economic era, their products or services market positioning has some expansion. In particular, the arrival of the new economic era, people's spending power is on the rise of the trend of development, which also means that consumer demand will be more diverse, personality, and the market shows a miniaturization, which enterprise market Marketing is more refined and targeted. Enterprise marketing products, services itself is gradually becoming popular, some products are rapidly imitated, special goods gradually evolved into a popular product; related characteristics of services is converted to a standardized service.

The Trend of Marketing Gets Green Development. The new economic era requires economic development towards low-carbon green mode, especially the current natural resources such as oil, water, coal and other consumption has been very serious, people have realized the importance of environmental protection, energy conservation, national and government at all levels of business development there is a corresponding policy [5]. In this way, the new economic era of corporate marketing also had a direct impact, that is the development of green marketing orientation. Specifically, many corporate marketing more and more attention to the interests of the public and the interests of consumers combined to create a good corporate image, to achieve good marketing 
results.

In summary, the impact of the new economic era on corporate marketing is very obvious, in addition to the impact of the above two points, but also on the way the enterprise marketing has a great impact, including corporate network marketing the most prominent, the way the time and place of the impact is very small, and even discounts have changed the way. All in all, the new economic era of the impact of corporate marketing is very large, if the enterprise is still stick to the previous marketing means do not change, companies are difficult to occupy a place in the new economic era.

\section{The New Thinking Direction of Enterprise Marketing Strategy at New Economic Era}

Enterprises carry out marketing is bound to be based on existing and potential market situation, combined with the economic development of the times to develop a corresponding marketing strategy. Therefore, the new economic era of enterprises to implement marketing from the following points to determine the direction of strategic thinking:

Change Marketing Thinking and Ideas. The new economic era and its impact on the marketing of enterprises in China has a prominent feature, companies must innovate the past marketing strategy thinking, change thinking and thinking. In this regard, you can start from three points: (1) to national policy as a reference, under normal circumstances the national policy for enterprise development, enterprise products, business services have a corresponding support and restrictions, on this basis, (2) to consumer market demand, the main purpose of enterprises to carry out marketing is to attract consumers, the new economic era of consumer products, services, and so have more than the market, the company's marketing strategy can be better adjusted; High demand, and consumer demand is diversified, personalized, for this enterprise marketing can start from the marketing strategy, methods to meet their needs, and then achieve the purpose of marketing; (3) attention to corporate marketing of the green, with the concept of marketing not only fit the new era of economic development needs, but also to create a good corporate image, which can also promote the latter part of the effectiveness of corporate marketing, but also to promote the new economic era of sustainable development.

Strengthen Cooperation and Open the Direction of Marketing Strategy. New era of knowledge, talent, technology and other needs continue to expand, the current era is the era of knowledge economy, so the enterprise development has the appropriate talent, technology in the market can occupy a certain position otherwise it is easy to be eliminated. This shows that the new economic era of enterprise competition is very intense. In order to cope with the fierce market competition, as well as for the good marketing pave the way, enterprises to strengthen cooperation in the way of marketing strategy is an important strategic step [6]. First of all, technological innovation and development is the norm of the new economic era, and there is no doubt that the competitiveness of enterprises with technology will be stronger, so if necessary, the relevant enterprises can strengthen cooperation to achieve win-win situation, joint research and development of new technologies, new products to provide new services, improve the competitiveness of enterprises. In addition, to strengthen cooperation between enterprises, enterprise production costs have been reduced accordingly, the enterprise economic benefits can be further highlighted. Finally, to strengthen the process of cooperation in the enterprise marketing and consumers to establish long-term relationship, the strategic direction of marketing can be further expanded.

Change the Way of Marketing. Enterprises to provide products, services, etc. are the key content of marketing, marketing needs to take full account of the product or service functions, the role, and how the enterprise products, services, functions, role presented in front of consumers, 
Attracting consumers is the need to deal with marketing links. In the new economic era enterprises to change the way marketing has become inevitable. The specific way to change the marketing can fully use the network platform. For example, enterprises can be a product or service through the network platform to publish relevant information such as product or service functions, product price concessions, etc., on the network to promote; or directly for the enterprise to establish their own marketing business department, network operators and other departments, and for the development of online marketing to improve the provisions, such as products or services from the offer, related to mail, after-sales service, and other related processing mode. Enterprises with the characteristics of the new economic era, but also the era of consumer demand, green and other related concepts, by changing the way marketing to achieve good marketing, and promote sustainable development of enterprises to enhance the economic efficiency of enterprises.

\section{Conclusion}

To sum up, the new economic era is the era of knowledge economy, is the era of network economy, low carbon green economy era, the development and operation of enterprises must be based on this to carry out marketing measures, which in the fierce competition among enterprises to gain a place. In order to make the enterprise marketing can adapt to the current economic situation, the above analysis of the impact of the new economic era, and to explore and put forward the three new strategic thinking of corporate marketing, that is, change marketing thinking and ideas to strengthen cooperation to develop marketing strategy and change the direction of marketing. Although the above discussion is not comprehensive, but still hope for the new economic era of enterprise marketing to provide some reference.

\section{References}

[1] Han Hua. New economic era of corporate marketing strategy of new thinking[J]. Modern marketing (late), 2014, 10: 4

[2] Li Qing. On the new economic era of enterprise marketing strategy of new thinking[J]. Business economics research, 2015, 02: 61-62.

[3] Zhang Jin. New economic era of corporate marketing strategy under the new thinking[J]. Journal of Chifeng University (Natural Science Edition), 2015, 13: 136-137

[4] Zhou Lan. Analysis of new economic era of corporate marketing strategy of new thinking[J]. Small and medium-sized enterprise management and technology (late), 2013, 01: 23-24.

[5] Li Xue. New economic era of enterprise marketing strategy of new thinking direction analysis[J]. Economic Research Guide, 2016, 32: 103-104

[6] Zhao Huiling. New thinking of enterprise marketing strategy under the background of new economy[J]. China Administration Information Technology, 2015, 24: 127-128. 